Journal of Critical Race Inquiry

Volume 7, Number 1 (2020) pp. 46-66

\title{
"Everyday Racism," “White Innocence," and Postcolonial Society: A Deeper Look into the Dutch Cultural Archive
}

\author{
Bas Dikmans \\ Cultural Anthropology and Development Sciences (CADES) \\ Faculty of Social Sciences, Catholic University of Leuven
}

\begin{abstract}
This paper explores Dutch postcolonial society through looking at it from the lens of critical race studies. In particular, this paper highlights the complex societal debate surrounding race, skin colour, and ethnicity in the Netherlands through examining the voices of Dutch individuals who come from an immigrant background and who are writing critically about these issues. Through looking at Surinamese-Dutch anthropologist Gloria Wekker's "white innocence" and Surinamese-Dutch critical scholar Philomena Essed's "everyday racism," this paper explains how colonial discourses of racial thinking still substantially influence Dutch society today. I then employ these concepts to examine the nonfiction writings of the Russian-Cameroonian-Dutch author Anousha Nzume's Hallo Witte Mensen ${ }^{1}$ (2017) and the Turkish-Dutch Zihni Özdil's Nederland mijn Vaderland ${ }^{2}$ (2015) as two texts that critically engage in, within the realm of popular culture, contemporary discussions about the position of race and the way it is ingrained in the dominant conception of Dutch national identity. In doing so, I provide insight into how "new" migrant-descent voices within the realm of Dutch popular media are actively challenging hegemonic ideas about race and racism.
\end{abstract}

Keywords: The Netherlands, white innocence, everyday racism, postcolonial society, cultural archive

\footnotetext{
${ }^{1}$ English translation: Hello White People.

${ }^{2}$ English translation: The Netherlands, my Motherland.
} 


\section{Introduction}

In November 2016, the Amsterdam municipality in the Netherlands bid farewell to the deeply rooted tradition of $Z$ warte Piet (literal translation: Black Pete) in the capital city (Misérus \& Van De Kolk, 2016). This provoked a widespread national discussion about whether other municipal authorities should continue to allow this highly controversial figure, or whether they should follow Amsterdam's example. Zwarte Piet is a character tied to the national festivity of Sinterklaas, celebrated each year on the fifth of December throughout the country. During this national feast, children are given presents and sweets, and sometimes adults also give presents and write poems to one another. The story recounted to children is that an imaginary figure called Saint Nicolas, based upon a Catholic saint - the former bishop of Myra during the third and fourth century A.D. - travels across the rooftops on his horse while throwing presents and sweets down the chimneys.

Every year, in mid-November, Saint Nicolas ceremonially arrives in the Netherlands (annually, a specific city is elected to host this event), where he makes his big entrance on a steamboat. He is aided by several of his historically black-faced, clown-like helpers, called Zwarte Piet. The figure of Zwarte Piet entered the Dutch cultural scene in the middle of the $19^{\text {th }}$ century, when the international fame of the blackface character in the United States of America was at its peak (Koning, 2018). It was first mentioned in 1850 in a Dutch picture book for children, St. Nicolaas en zijn knecht, which translates to Saint Nicolas and His Helper. Almost 170 years on, painting one's face black to embody Zwarte Piet is still a widespread Dutch custom.

However, the municipality of the largest city in the Netherlands put an abrupt end to this tradition in 2016 during the official entrance of Saint Nicolas. Actors playing the part of $Z$ warte Piet were only given semi-painted black faces through the use of soot marks. This initiative, taken by Amsterdam, was a response to the recent rise of postcolonial and antiracist critiques on $Z$ warte Piet that were spurred on by activist groups composed of Dutch secondor third-generation immigrants. Their central critique is that the figure emerges from the historical reality of the $17^{\text {th }}$ century Dutch colonial empire's Black child slaves, and as such these activist groups call for a change in the representation of Zwarte Piet, or for the abolition of the figure altogether. This public discussion about $Z$ warte Piet has raised strong emotions among Dutch citizens, evoking questions about Dutch heritage and identity, as well as the cultural productions and the narratives that construct a sense of what "being Dutch" means (Rodenberg \& Wagenaar, 2016). In the aftermath of Amsterdam abolishing the figure of Zwarte Piet, other Dutch municipalities — among them Den Haag, Utrecht, Maastricht, and 
Leiden - indicated their ambition to alter the character in upcoming years, and to increasingly move towards a more universal and multi-racial Piet figure. It was announced in September of 2019, in fact, that the figure of $Z$ warte Piet would be prohibited in its totality during the official entrance of Saint Nicolas in Apeldoorn, on $17^{\text {th }}$ November, 2019 (Takken \& Metselaar, 2019).

As this example shows, the discussion about the history of slavery in the Netherlands has become a much debated and highly polarized topic. Arguably, this is due to a growing group of minority voices of non-Dutch descent-namely, second- and third-generation immigrants - critically addressing these issues. Despite these important efforts, the contemporary implications of the legacy of slavery and colonialism in the Netherlands have yet to become an accepted mainstream topic of conversation (Weiner, 2014). Gloria Wekker (2016), a Surinamese-Dutch anthropologist with a specialization in the field of gender studies and a leading figure in the Netherlands with regards to the critical study of whiteness, coined the term "white innocence" (p. 29) as a way of capturing the paradoxical relationship between historical slavery and the mark it still leaves on everyday life in the country. Specifically she describes how, on the one hand, race (in relation to gender, sexuality, and class) evokes passionate feelings, sometimes even resulting in acts of aggression among white Dutch citizens, while on the other hand "the reactions of denial, disavowal, and elusiveness reign supreme" (2016, p. 1) with regards to adequately addressing issues of race and racism. She puts her conceptualization of white innocence within the theoretical confines of Edward Said's "cultural archive" (1993, p. 52). Writing about the central influence of imperialism in $19^{\text {th }}$ century European society, Said argues that the cultural archive consists out of a "particular knowledge and structures of attitude and reference [that presuppose] that subject races should be ruled, that there are subject races, that one race deserves and has consistently earned the right to be considered the race whose main mission is to expand beyond its own domain" (Said, 1994, p. 52-53). Wekker (2016) thus argues that, although slavery was abolished more than a century ago, Dutch society has not yet come to terms with acknowledging and deconstructing the cultural archive that has been at its roots, and that this still has implications for the relationship between persons with different origins in the Netherlands.

Surinamese-Dutch critical scholar Philomena Essed has also made important contributions on the theme of race and post-colonialism in the Netherlands. She has shown how colonialism and, in particular, colonialism's ongoing influence on the hegemonic

\footnotetext{
${ }^{3}$ Witte Onschuld.
} 
discourse surrounding themes of whiteness and national identity, is still is an integral part of Dutch society (Essed, 1984; Essed, 1990; Essed \& Hoving, 2014). One of her most valuable insights is her conceptualization of "everyday racism"," or "the various types and forms of racist expressions that ethnic groups experience in the day-to-day interactions with (members of) the more powerful (white) group ${ }^{5 "}$ (Essed, 1984, p. 87). Essed argues that Dutch society has developed a blind spot in talking about and discussing the more mundane forms in which racist practices remain omnipresent. This is, in her opinion, due to the fact that the scientific and the societal debate about racial, cultural, and ethnic identity in the Netherlands has, for a long time, been dominated by individuals with a majority (white) background (Essed, 1984). Essed was the leading author on the theme of racism and racial relations in the Netherlands in the 1980s and is, as mentioned earlier, herself a daughter of Surinamese parents. She influenced other contemporary postcolonial Dutch writers (such as Nzume, 2017; Özdil, 2015; and Wekker, 2014; 2016; to be discussed later in this paper) to write critically about the relevance that skin colour, ethnicity, and racial constructs still have in Dutch society today.

This purpose of this paper is to provide greater insight into the complex societal debate surrounding race, skin colour, and ethnicity in the Netherlands through examining the voices of Dutch individuals who come from an immigrant background, and who are writing critically about these issues. In the first section of this paper, I define the two concepts central to my analysis, Wekker's “white innocence” (2014; 2016) and Essed's “everyday racism” (1984), together with an explanation of the contemporary relevance of white innocence and everyday racism in Dutch society. I then briefly look at Dutch decolonization practices after World War II. I contend that looking more deeply into Dutch approaches and policies towards decolonization, particularly those that took place after World War II, provides insight into why the cultural archive of European imperialism was never adequately discussed and questioned and, thus, why matters of race remain so contentious in contemporary Dutch society. I argue that tracing the history of Dutch decolonization practices provides a better idea of how specific ideas about race and colonialism have become rooted in different areas of Dutch postcolonialist society, such as in education, work, and immigration policies.

Thirdly, I relate this theoretical and historical context to contemporary literature that deals with these problematic issues. Specifically, I examine the writings of the RussianCameroonian-Dutch author Anousha Nzume's Hallo Witte Mensen ${ }^{6}$ (2017) and the Turkish-

\footnotetext{
${ }^{4}$ Alledaags Racisme.

5 "Als ik van alledaags racisme spreek heeft dat betrekking op de verschillende typen en uitingsvormen van racisme die etnische groepen ervaren in de alledaagse omgang met (leden van) de meermachtige (witte) groep". ${ }^{6}$ English translation: Hello White People.
} 
Dutch Zihni Özdil's Nederland mijn Vaderland ${ }^{7}$ (2015). I chose these two texts because of their structured and detailed accounts of the way racial classifications and stereotypes work in the Netherlands. As such, these two pieces of work are particularly relevant because they critically engage in, within the realm of popular culture, contemporary discussions about the position of race and the way it is ingrained in the dominant conception of Dutch national identity. This is further emphasized by the fact that their authors are at the forefront of a growing group of dissenting minority voices working passionately towards the deconstruction of racialized biases and towards the emancipation of non-white voices into the Dutch cultural archive and, respectively, Dutch society as a whole.

Thus, in this paper I want to unravel the different processes that have made the issue of race such an important and contested topic in the Netherlands today. In addition to this, I want to understand how the critical voices of second- and third-generation immigrants have entered the scene and reshuffled debates around colonialism, race-based ideologies, and the various factors shaping Dutch identity. The main contribution of this article, particularly for an international audience, is an analysis of two contemporary Dutch cultural texts, written by two Dutch immigrant authors from diverse backgrounds (Anousha Nzume, a Dutch woman of Cameroonian-Russian descent, and Zihni Özdil, a Turkish-Dutch man) which can give new insights into the workings of race and whiteness in the specific geo-cultural confines of the Netherlands. Specifically, by examining Özdil and Nzume's work through Wekker and Essed's concepts of white innocence and everyday racism, this paper offers a unique analysis of the ways in which antiracist critiques are voiced in mainstream autobiographical literary productions in the Netherlands by Dutch authors of migrant-descent. As such, this paper explores how the works of Nzume and Özdil open up a new discursive sphere within the realm of Dutch popular culture that unveils the ways in which postcolonialist theory in the Netherlands is being negotiated, redefined, and liberalized and how, through these processes, a more nuanced and productive discussion around race is gradually rooting itself in everyday life and in mainstream Dutch society.

\section{Everyday racism and white innocence}

To understand the meaning of the notion of "everyday racism," it is useful to understand the origins of the concept of race. Developed in the 17th century, the actual term

\footnotetext{
${ }^{7}$ English translation: The Netherlands, my Motherland.
} 
"race" originates from the field of physics, exemplifying the desire to find a "means to classifying human bodies" (West, 2002). In the $18^{\text {th }}$ century, the famous physicist Carl Linnaeus was the first person to attempt to give a structured account of racial categorizations (see his infamous "Systema Naturae" (1735) for more details). Afterwards, the notion of race, and the perceived necessity to categorize based on racial characteristics, intensified in Europe and the West from the $18^{\text {th }}$ century onwards. This included an increasing use of race and racebased terms in languages, as they increasingly became a way to define and emphasize difference with the "Other," and to emphasize the positive characteristics of a specific group (e.g., white) (Banton, 1999). During the Age of Enlightenment during the $18^{\text {th }}$ century in Europe, philosophers such as Kant, Hume, Montesquieu, and Voltaire speculated about the nature of humankind, and strengthened the discourse of dividing the world into various racial categories, with those categorized as "white" considered the "norm" (West, 2002). By the late $18^{\text {th }}$ century, racial identity and national identity began to merge, and the concept of race - which began as a so-called scientific endeavor attempting to "objectively" study the difference between peoples - became an increasingly political and cultural notion (MorrisReich \& Rupnow, 2017).

According to Essed (1984), in order to understand the extent of racism and the ways in which racism operates in society, one has to differentiate between three different levels of racism, namely 1) cultural racism, 2) institutional racism, and 3) individual racism. Cultural racism, Essed (1984) argues, has to do with painting a picture of the "Other" through cultural products such as books, TV, and newspapers, but also through religion, language, or artistic expression. She explains how, through consistent reproduction over time, ideas about the Other have become normalized, creating a feeling of neutrality to the perceived differences between groups of people. In her infamous essay, "Writing Against Culture," anthropologist Lila Abu-Lughod (1991) demonstrated how the two concepts of culture and race (which she considers as being antonyms as race is, according to her, natural and innate, while culture is "learned and changeable" (Abu-Lughod, 1991, p. 143)) became more and more entangled with each other within mainstream as well as academic discourse. This gave way to forms of cultural essentialism or culturalist explanations of race-based inequalities between groups of people (Visweswaran, 1998). In the Netherlands, I argue, racist sentiments and essentialist representations regarding individuals and groups of people perceived to be different by virtue of their phenotypic appearance have become hidden under the mantle of culture and cultural differences, making them difficult targets for postcolonial antiracist critiques (Balkenhol, Mepschen, \& Duyvendak, 2016, p. 16). 
It is a small leap from cultural racism towards institutional racism, Essed explains (1984). Institutional racism cannot be seen as isolated from cultural racism, as reproduced and normalized ideas about different groups of people also influence bias and perceptions influencing government policies and the ways in which companies work (Essed, 1984). Examples of institutional racism include ethnic labelling by the police or employers who, whether intentionally or unintentionally, do not invite a person named "Mohammad" for a job interview. The third category of racism, individual racism, Essed (1984) defines as encompassing all interpersonal interactions in either public or private spheres. For example, which friends you choose to have (or not have), where you decide to live, as well as varying encounters with other individuals, such as at the tram stop or local Starbucks. By dissecting the concept of race into these three categories, Essed (1984), in an academic tradition that originated in Fredric Barth's work on ethnicity (1969), categorizes racism as a process that has less to do with the individual and more about the forming of groups and boundaries within society. In the case of the Netherlands, as almost everywhere else, the individuals who are at the forefront of creating these racial boundaries are white, and they are maintaining these categorizations, whether consciously or unconsciously, for their own benefit. As a result, this white majority has an interest in perpetuating racism at all three of the levels Essed defines (1984).

All the different structures, rules, and behaviors that keep these distinctions intact in day-to-day interactions between this white majority and first-, second- and third-generation immigrants of colour in the Netherlands is what Essed (1984) then calls "everyday racism," or the way that cultural, institutional, and individual racism have normalized racist behaviour and attitudes towards people of colour in Dutch society. This analytical concept is, in Essed's book (1984), defined from the perspective of people of colour who experience these different types of discrimination and repression. Abu-Lughod (1991) already argued for the anthropological world to prioritize "anthropologies of the particular," emphasizing the need to focus on "particular individuals and their changing relationships...[in order to] subvert the most problematic connotations of culture: homogeneity, coherence, and timelessness" (p. 154). This paper departs from this vantage point in order to closely examine the particular experiences of Nzume (2017) and Özdil (2015), two authors from immigrant backgrounds who, I argue, confront these situations of everyday racism in the Netherlands through their nonfictional and autobiographic writing style.

Jacobson (1999) points out how the construct of race is fluid, and changeable over time and across space, highly influenced by "a history of power and its disposition" (p. 9). In other words, some "racial categories," which have historically been considered distinct groups such 
as Celts, Slavs, or Hebrews, are nowadays not defined as such. Wekker (2016) connects this to the fact that the colonial archive in the Netherlands has managed to frame the discussion about race around Blackness, omitting the fact that whiteness cannot be seen as neutral and separated from its antonym. She argues that, from the days of Dutch colonialism in the $16^{\text {th }}$ and $17^{\text {th }}$ centuries, a dichotomy was created within Dutch culture between whiteness and Blackness (Wekker, 2016). Whiteness, on the one hand, has been postulated as the "norm," or as neutral and unwritten and therefore not necessary to subject to any critical scrutiny. Blackness, on the other hand, has been depicted as detrimentally exotic, or as "inferior, intellectually backward, lazy, sexually insatiable and always available" (Wekker, 2016, p. 3). The word "blank" that was, until recently, generally used to refer to a white skin colour in the Dutch language, is a clear example of emphasizing the perceived neutrality of whiteness.

Wekker's (2016) concept of white innocence is tightly connected to this. It is, in her own words, a representation of the Netherlands "as being a small, but just, ethical nation; color-blind, thus free of racism; as being inherently on the moral and ethical high ground, thus a guiding light for other folks and nations" (p. 2). Therefore, when trying to unravel the Dutch cultural archive, she argues, it is vital to be aware of the structural persistence of this specific valorization of whiteness as an antonym of Blackness, and to see these two terms as defined in relation to one another. That is, as much as whiteness is valorized, Blackness is denigrated.

It is imperative to discuss more in-depth the historical roots of this cultural archive and the impact it has had on contemporary Dutch society throughout modern history. It is also important to examine the influence this cultural archive has had on negotiating the complex interplay of several hundred years of race relations in a country that owes its cultural heritage and accumulated wealth to centuries of colonialist dominance. In a contemporary comparative framework it is commonly accepted that the Dutch cultural archive cannot be seen as isolated from the broader Western-European context. However, there are several particularities that make the Dutch cultural archive explicitly Dutch. The most prevalent, according to Wekker (2014), is the "strong attachment to a self-image that stresses being an innocent, just, and small ethical national, [of] being a victim rather than a perpetrator of violence" (p. 174), making a connection between the relatively small geographical confines of the Netherlands and its self-morale as being too minor to have any global impact whatsoever. Following this logic, the pretention of white innocence is at the core of Dutch national identity making.

In order to better understand the true significance and prevalence of the persistent cultural archive of white innocence and everyday racism in Dutch society, it is worthwhile to compare the Dutch context with that of the United States. Essed and Hoving (2014) in fact argue strongly that the particularities of the normalization and even denial of racism in the 
Netherlands is best understood in comparison with the ideologies of colour blindness in the United States (Essed \& Hoving, 2014). In the U.S. Essed and Hoving (2014) argue, "communities and critical scholars have developed strong and alert voices to intervene against racism...even while racism remains insidious and widespread... The Netherlands, in contrast, has remained stagnant and generally accepting in the face of racism" (p. 11). In other words, different historical and political attitudes towards race ideologies and racism have, in the case of the Netherlands, led to extremely narrow definitions of racism, making it easier for a white majority within Dutch society to collectively ignore racism and to be able to control the discursive sphere in which discussions about racism are acted out.

In the re-edited Dutch edition of Wekker's book (2018), she included an extra chapter discussing the reception of her book, White Innocence: Paradoxes of Colonialism and Race, in the Netherlands, demonstrating how these aforementioned valorizations of whiteness and the manifestation of the cultural archive came to the fore, and were hardly put to question after the publication of the book. Predominantly, she describes disbelief surrounding the discussion of whiteness and self-perceived innocence thriving in the Netherlands, noting that she has been, on various occasions, insulted and even threatened with lawsuits for inciting aggression and racist inclinations towards (white) Dutch individuals. The main conclusion she makes in this chapter is that the reception of her book has been exemplary for the perspective she takes in the very same book, which is that there is an overall rejection of her critique by white readers who are ruminating on the dominant discourse of whiteness. She observes this especially within the realm of media outlets - in her words, a traditional, white-dominated media world - and touches on the fact that the discursive sphere of social media has been more receptive, as different categories of people are more appreciative of her work and this opens the opportunity for a more liberalized and diversified discussion of her book.

Additionally, Wekker (2014; 2016) and Essed (1984; Essed \& Hoving, 2014) postulate an intersectional approach towards analyzing the situation of people of colour in the Netherlands. Such an intersectional approach was first defined by Kimberlé Crenshaw (1989) to emphasize the unique and intersecting experiences of discrimination that Black women face as a result of embodying multiple oppressed identities - in particular, being women and being Black. Taking a similar approach, Wekker and Essed argue from the vantage point that racism, sexism, and classism cannot be seen as isolated concepts. In other words, one may experience discrimination because they are a woman, or have a dark skin colour, or come from a lower socio-economic background, but one will experience multiple and unique forms of oppression as a result of embodying a mixture of these categories. Thus, the experience of discrimination of a white woman might overlap with the experience of a Black woman in its gender 
dimension, but it is different in the sense that a Black woman must also face discrimination on account of being Black. Both Wekker and Essed take women of colour as their primary group of analysis to show how these different forms of oppression and exclusion are woven into each other in Dutch society. I will come back to this point in the following sections, as Nzume (2017), one of the two authors with whom this article is concerned, uses this intersectional perspective in her work as well.

This section sheds light upon the etymology of race as a cultural and political construct in the colonial Netherlands, as well as its intensification in the $18^{\text {th }}$ century through a growing importance of nationalist and enlightenment ideology. These historical developments form the conceptual backbone for the social climate of majority-minority relations which are specific to the context of the Netherlands in the postcolonial era, reflecting Essed's and Wekker's conceptualizations of "everyday racism" and "white innocence" (Essed, 1984; Essed \& Hoving, 2014; Wekker, 2014, 2016). The following section will give a brief historical overview of the process of Dutch decolonization, and in doing so provide a more in-depth understanding of the specific context in which Nzume and Özdil are formulating their critiques of their position in Dutch society.

\section{Decolonization in the Netherlands}

Dutch decolonization started after World War II, with the Independence of Indonesia in the immediate aftermath of World War II, followed by the independence of Surinam in the 1970s. However, this decolonization did not happen according to a well thought out plan and, as a result, the Netherlands was surprisingly unprepared during the 1940s — as well as again in the 1970s - for the postcolonial migration that decolonization engendered (Oostindie, 2010). Oostindie and Klinkers (2003) speak about Dutch decolonization policies in the context of what they term "consociational democracy" (p.13), describing the tendency within Dutch politics to make coalitions across political and religious ideologies which resulted in a political landscape that focused more and more on consensus between these different groups (or $z_{\text {uilen }}{ }^{8}$, as they were called in the Netherlands), rather than polarization. This political context is referred to with the Dutch word verzuiling, or pillarization. It was a necessary and arguably commendable approach to reorganize society after World War II, but with so many diverse standpoints and values it made Dutch politics slow and difficult. This meant that focus

\footnotetext{
${ }^{8}$ English translation: Pillars.
} 
on the decolonization of the overseas colonies, where secular rule had the preference (Fadil, de Koning, \& Ragazzi, 2019), waned (Oostindie \& Klinkers, 2003). As such, the mass emigration of families from Suriname to the Netherlands during the country's independence in 1975, where in total one quarter of the population left the country between 1970 and 1980 (Hoefte, 2014), exposed the tensions between these first-generation immigrants and Dutch citizens.

As the Netherlands became increasingly secular and "a strong wave of individualization pulled the rug from under verzuiling" (Oostindie, 2010, p. 9), the assumption was that newcomers would follow the same process. Newcomer immigrants were, at first, allowed to keep and openly adhere to their own cultural traditions and/or religious identity, but the (in retrospect, naïve) idea was that, through their integration in Dutch society, newcomers would eventually follow the same path of individualization and secularization. This only served to enhance and even exacerbate the gap of expectations between the people living in the Netherlands and the new immigrants. Today, this tension has intensified as increasing globalization augmented the diversity of immigrants coming to the Netherlands, and the discussion about a national identity became more polarizing vis-à-vis minority groups in the country (Oostindie, 2010). At the same time, this growing polarization in Dutch society is exacerbated by the inequalities experienced by many immigrant groups, as exemplified by their lower levels of education, work, and income, when compared to native Dutch people (Centraal Bureau voor de Statistiek [CBS], 2016). These statistics should be read with caution, however, as they deal with first- and second-generation immigrants vis-à-vis native Dutch persons. This dichotomy leaves many types of structural inequalities out of the picture. One can, for instance, be a native Dutch person with black skin and still be more excluded from getting a job or higher education than a white immigrant. Or, a female second-generation immigrant might find herself in a more precarious situation than her male counterpart.

How can these politico-historical developments be understood in the context of the cultural archive, white innocence, and everyday racism? A deeper look into the Dutch educational system provides valuable insights. Looking at the ways in which colonialism is addressed in the Dutch school system, several authors have shown that colonialism is often depicted as unproblematic. Hira (2012), for example, claims that in Dutch universities, the hegemonic way of portraying colonialism is through describing it as "a normal form of social relations between human beings rather than a system of exploitation and oppression" (p. 53), and refers to this as "scientific colonialism." In addition, Weiner (2014) uses the concept of racial Europeanization (first coined by the critical race theorist Goldberg in 2006) as a way of showing how, in the Netherlands and throughout the centuries, whiteness has been de- 
politicized through silencing and omitting the discussion surrounding colonial regimes. This is especially true with regards to the absence of documented experiences of first-, second- and third generation immigrants in the Dutch educational curricula, including primary and secondary education but equally within higher education and universities (Nimako, 2012). Further, Weiner (2014) contends, where discussed at all minorities are blamed "for their individual failings to socioeconomically assimilate, thereby bringing inequality upon themselves" (p. 330). Thus, one could look at structures of exclusion within the context of the Dutch educational system and adjacently work towards educational reforms as a way of changing the mentalities underlying racial inequalities and the categorization of migrantdescent Dutch people as essentially inferior to others.

Hira (2012) shows how generations of Dutch colonialism has influenced the minds and ideas of the colonizer as well as the colonized who also, in time, "have been molded to accept and propagate colonial ideas" (p. 63), which in turn impacts the education systems in the Netherlands as well as in former Dutch colonies. One could argue that this is not a uniquely Dutch phenomenon, but rather a general principle of colonialism. Regardless, a general shift towards the inclusion of critical race studies, immigration studies and/or Black European studies in academic curricula is needed to meaningfully and structurally incorporate discussions of whiteness into the mainstream Dutch debate (Nimako, 2012).

As this section has shown, political developments of the post-World War II period in the Netherlands, together with the omission and silencing of racial bias that comes out of the Dutch cultural archive by a white majority, have led to a race-based hierarchical societal structure in the country. The Dutch educational system leaves little possibility to challenge and denounce established viewpoints, as there is not enough incentive for schools and universities to diversify their curricula, which is a necessary prerequisite to tackle "scientific colonialism" (Nimako, 2012; Weiner, 2014). These dynamics are similar to processes of decolonization in other former colonialist west-European countries, such as Great Britain (Small \& Nimako, 2012); however, an increasingly restraining and tense political situation in the Netherlands has made matters of racism difficult to discuss, as those who raise the issue are accused of being overly sensitive or petty (Essed, 1984). The next section shows how the intricacies of these concepts come through in contemporary alternative voices such as Nzume (2017) and Özdil (2015), who are actively changing the timber and tone of the debate surrounding racism in the Netherlands. 


\section{Nzume and Özdil: Opening up the cultural archive}

In this section, I discuss the works of two contemporary nonfictional authors, Anousha Nzume (2017) and Zihni Özdil (2015), who both come from immigrant backgrounds and who, among other contemporaries, have provoked a radical rethinking of the themes of whiteness, ethnicity, and national identity in the Netherlands. I have chosen to focus on the experiences of these two authors as a framework of analysis although they are, arguably, confronted by very different types of racialization to one another. However, they both build upon the analytical insights and the academic work of Wekker $(2014 ; 2016)$ and Essed (1984; Essed \& Hoving, 2014) with regards to contemporary Dutch postcolonialist critique, while at the same time bringing their academic work out into the realm of mainstream Dutch media. Both Nzume and Özdil share the objective of scrutinizing and discussing the dominant white self-image throughout the country, albeit in their own particular ways. Through discussing excerpts from Nzume and Özdil's work and highlighting the two authors' reactions to and interpretations of certain events, I will demonstrate how Wekker $(2014 ; 2016)$ and Essed's (1984; Essed \&Hoving, 2014) theoretical concepts of white innocence and everyday racism are embedded in real-life struggles.

Özdil (2015) is of Turkish origin, and problematizes the common ideas about what being Dutch entails in Nederland Mijn Vaderland. Wekker (2018) even refers to Özdil in the additional chapter about the reception of her book in the Netherlands, highlighting the parallel struggle between her work and Özdil's as he too concentrates heavily on institutional racism in The Netherlands. Özdil begins his book with an anecdote about a colleague professor in the Erasmus University College in Rotterdam, where Özdil worked at the time as an assistant professor on themes concerning world history, citizenship, and political economy. One day, Özdil writes, his colleague entered his office and asked him, somewhat surprisedly, if Özdil also used the QWERTY-keyboard in his own country. Somewhat baffled, it took a few seconds for Özdil to realize that what his colleague actually wanted to ask was if people in Turkey used the same keyboard as those in the Netherlands. Özdil then concludes that the man associated his black hair and the name Özdil with exoticness, otherness, or "nonDutchness."

Nzume (2017) relates a similar experience in her own book. Nzume (2017), herself a child of a Russian mother and a Cameroonian father, wrote the book Hallo Witte Mensen in which she provides the white Dutchman with a mirror to reflect on his or her own position in society. In her book she recounts how, when she was young, she remembered the celebrations of Sinterklaas at her primary school, and the many black-faced helpers, or Zwarte Piet, who 
accompanied him. She recollects how ashamed she felt at the sight of her friends' parents with their faces painted black and acting in a silly way. Because of her skin colour, Sinterklaas even asked her to help out next year, and jokingly added that she did not even have to paint her face. Because of her skin colour, Nzume recounts, she was differentiated from the rest of her class, in the same vein as Özdil was differentiated because of his dark hair and the perceived exotic nature of his last name. These are two illustrative examples of how everyday racism is visible in ordinary and mundane situations, as a manifestation of the constantly repeating, day-to-day forms of racism that have become normalized in mainstream Dutch society (Essed, 1984). When her own children started going to school, Nzume remembers how she tried to address the issue of $Z$ warte Piet during a parents' evening. The reaction she got was far from an understanding one. "[It was] as if I was concocting a plot to murder Máxima" ${ }^{9 "}$ she writes (p. 97). Nzume even confesses that she unintentionally internalized the whole discourse of $Z$ warte Piet, as she realized that, when her son came home from school and conveyed to her that he had been called Zwarte Pietje (meaning "little black Pete"), she had not been supporting him but instead had been trying to emphasize the positive aspects of being referred to as such.

Both Özdil (2015) and Nzume (2017) emphasize that speaking out against these manifestations of everyday racism results in two things. For one, their claims are often trivialized. In numerous occasions they describe receiving reactions from white Dutch people such as "it was just a joke"; "I did not mean it that way" or, in the case of Zwarte Piet, "it is for kids, don't take it so seriously." The core message they receive in these acts of everyday racism comes down to: "Do not complain about such a trivial thing!" These interactions can also highlight the concept of white innocence through white people's process of trivializing, belittling, and silencing a person of colour who draws attention to incidents of racism (Wekker, 2016). Secondly, these trivializations can turn into anger when the person drawing attention to racism does not give in, and in these cases, Wekker (2016) argues, the true colour of the cultural archive shows itself. That is, the claimant is left with two options: back down immediately or face the wrath of the white majority.

Özdil (2015) also questions the linguistic and terminological manifestations of everyday racism and white innocence in the Netherlands. To show how manifestations of oppression and exclusion are heavily ingrained in institutional and political language, he uses

\footnotetext{
9 "Toen ik probeerde uit te leggen dat ik Zwarte Piet een hardnekkige vlek op het koloniale tafelkleed vond, werd ik door de andere ouders, op een Surinaams-Nederlandse moeder na, aangekeken alsof ik een moordcomplot op Máxima aan het beramen was" [Máxima is the Queen of the Netherlands, and the wife of King Willem-Alexander].
} 
the concept of the allochtoon. Allochtoon, a Dutch term used to refer to first- and secondgeneration immigrants literally meaning "emerging from another soil" (Verwey-Jonker, 1971), is one of the clearest examples of institutional racism that is particular to the Dutch situation. As Özdil argues, allochtoon was from its conception a racist concept, referring to individuals with a "remarkable appearance-especially with regards to their skin color" (as described in the book where allochtoon was first defined, published by the Dutch Ministry of Culture, Recreation and Social Work in 1971; see Verwey-Jonker, 1971). Similar to Wekker and Essed's line of thinking (Essed, 1984; Essed \& Hoving, 2014; Wekker, 2014; 2016), Özdil claims that "the cultural positioning of everything that is not white, as opposed to 'the Dutchman', is a reflection of the fact that we did not expand Dutch citizenship within the reality of a multiracial country ${ }^{10 \prime}$ (p. 116). Özdil shows how the hypocrisy of the word allochtoon is manifested in the Dutch refusal to refer to the former Queen of the Netherlands from 1980-2013 and mother of King Willem-Alexander, Princess Beatrix, as an allochtoon, despite being of German descent. As a solution, Özdil (2015) proposes to copy the American method of referring to different persons with their current nationality as well as their origins. In the same way as people are referred to as "African-American" in the United States, he argues, Dutchmen could opt to do the same, using, for instance, "Surinamese-Dutch" or "Turkish-Dutch."

Lastly, Nzume (2017) uses an intersectional approach to show how for her, in contrast with Özdil, the fact that she is a Black woman compounds the processes of exclusion, exoticization, and Othering that she experiences. She remembers how, when she was younger and going out with friends, sexualized ideas about how Black women are and should behave were projected on her by interested young (white) men. Wekker (2016) calls this sexual racism, the stereotype that Black women have a high sex drive and are insatiable and always available and that which is constantly reproduced through public expectations and social interactions. When Black women defy these expectations, Wekker shows, it often leads to aggressive confrontations with a dominant white (and male) group and it is during these instances that the power imbalance-tipped in the favour of the white majority-is most apparent. As such, Nzume (2017) often found herself trapped in the stereotypical image she felt she was supposed to be portraying to others.

By using concrete examples provided in Nzume and Özdil's work, this section sheds light on the ways in which everyday racism and white innocence are ingrained into Dutch

10 'De culturele positionering van alles wat niet wit is als tegenovergesteld aan 'de Nederlander', is een weerspiegeling van het feit dat we het Nederlanderschap niet mee hebben laten ontwikkelen met de realiteit van een multiraciaal Nederland". 
society. Nzume and Özdil give several insightful chronicles about how the cultural archive still leaves its mark on the minds of white people in the Netherlands. In Özdil's (2015) case, he is mainly seen as different from the norm because of his family name, and less on his outward appearance (although this is a relative observation and should not be disregarded completely). His personal experiences, along with the fact that he is a historian, make him focus on the epistemology of concepts and the institutionalized forms in which certain types of racism and exclusion come to the fore in the Netherlands. Nzume's (2017) account as a Black woman is more intimate, and she recalls how her skin colour was the main catalyst of her being treated differently in Dutch society. Both authors are part of a new generation of engaged individuals openly challenging everyday racism and white innocence in Dutch society and offering much-needed alternative voices to the mainstream notions surrounding race and colonialism in the Netherlands. As such, they are paving the way for the emancipation of an, until recently, silenced group of first-, second-, and third-generation immigrants.

\section{Conclusion}

After Dutch decolonization took place, a substantive number of immigrants from the ex-colonies came to the Netherlands to live, work, and study (Hoefte, 2014; van Niekerk, 2004). In the ex-colonies as well as in the ex-colonizing countries, the cultural archive left a scar on the mentality of the former subjects of the colonial empire, making the process of decolonization and inclusion for people who immigrated for a better future difficult, frustrating, and slow. As the infamous Surinamese freedom fighter Anton de Kom stated in the first half of the $20^{\text {th }}$ century:

There is no better means to foster the feeling of inferiority in a race, than these history lessons, where without exception the sons of another people are being mentioned and praised. It has taken me a long time before I had liberated myself fully from the obsession that a negro always and unconditionally had to be the lesser of any white person. ${ }^{11}$ (de Kom, 1934, p. 50)

\footnotetext{
11“Geen beter middel om het minderwaardigheidsgevoel bij een ras aan te kweken, dan dit geschiedenisonderwijs waarbij uitsluitend de zonen van een ander volk worden genoemd en geprezen. Het heeft lang geduurd voor ik mijzelf geheel van de obsessie bevrijd had, dat een neger altijd en onvoorwaardelijk de mindere zijn moest van iedere blanke".
} 
Colonization has left its traces all over the world. In the case of the Netherlands, these places are, among others, in Indonesia, Surinam, and in the Caribbean. However, this paper has shown that it is an illusion to think that it did not leave its mark on the colonizing society as well. Images, travel accounts, letters, and even people travelling from the colonies to the Netherlands shaped the mentality and worldview of the Dutch vis-à-vis others (Wekker, 2016). From Sarah Baartman, a South African woman belonging to the ethnic group of the Khoi whose body was exposed and exploited for its "unique" attributions in various museums in Europe in the beginning of the $19^{\text {th }}$ century (see Wekker, 2016, p. 95-96), until Alleen maar nette mensen ${ }^{12}$ in the beginning of the $21^{\text {st }}$ century, the cultural archive has remained a persistent virus in Dutch postcolonial society.

This paper has shown that Wekker's (2016) concept of white innocence and Essed's (1984) notion of everyday racism are of particular importance for understanding Dutch society nowadays. This paper has also argued that there is a specific attitude towards issues of race, ethnicity, colonialism, and national identity in the Netherlands that weigh heavily upon minority groups living in the country. This has been largely evaded by the white Dutch majority through exclusionary processes in schools and universities (Nimako, 2012) and by political institutions (Wekker, 2016) that have been heavily white-dominated and oriented towards the preferences and belief systems of the white majority. Although the political tide is slowly changing, the situation has until now not changed structurally.

This paper has also demonstrated the power imbalances inherent in discussing and debating themes of whiteness and racism in the Netherlands as, until recently, a brave coloured woman who wants to address the issue of $Z$ warte Piet or a valiant Turkish-Dutch man who wants to address exclusionary practices on the basis of his last name would have been silenced, trivialized, and not taken seriously. It is important to note that I do not want to argue that these imbalances have shifted completely, but as this paper illustrates, mechanisms to change the public attitude have been set in motion in the last couple of years.

Contemporary individuals of migrant backgrounds have increasingly started to challenge the cultural archive, through books — as the cases of Özdil (2015) and Nzume (2017) show — but also for instance in art (some examples are AiRich, Charl Landvreugd, Brian Elstak, Tessa Boerman and Quincy Gario) and in politics. The Netherlands now in fact has two political parties that represent specific ethnic/racial minority groups: DENK, which has two seats in

\footnotetext{
${ }^{12}$ English translation of Alleen maar nette mensen is Only decent people, a book by Dutch author Robert Vuijsje in 2008 and made into a movie in 2012 which was criticized for grossly exaggerating cultural stereotypes towards Black people and Jews (see Essed, 1984, p. 35-39).
} 
parliament and mainly representing people from Turkish descent; and Bij1, which currently does not have any seats in parliament, but they have an explicit emancipatory civil rights agenda and an intersectional focus on women, Blackness (and, consecutively, whiteness), and minority groups.

American Black novelist and activist James Baldwin once wrote, "God [...] is white" (1963, p. 344). Thanks to the work of Black activists such as Baldwin the healing of the wounds that generations of slavery, colonialism, and exclusion have carved upon the mentality and identity of Black and white citizens in the U.S. has, slowly, begun. In the Netherlands, as this paper has shown, the process of acknowledging and, subsequently, tackling the legacy of historical colonialism has been slower and less abrupt, which has resulted in the neglect of important critical inquiry of racial inequality by a white dominant majority with no interest in bringing these types of debates into the open. Now, new voices such as Nzume's and Özdil's are entering the scene, raising questions about race, whiteness, and national identity. These are interesting times for the Netherlands and, though nobody knows what the future will bring, Baldwin's spark found its way to writers such as Nzume and Özdil, and their emancipatory agenda and postcolonial critique have permanently rooted themselves into the Dutch cultural archive.

\section{References}

Abu-Lughod, L. (1991). Writing against culture. In R. Fox (Ed.), Recapturing anthropology (pp.137-162). Santa Fe, NM: School of American Research Press.

Baldwin, J. (1963). The fire next time. New York: Dial Press.

Balkenhol, M., Menschen, P., \& Duyvendak, J. W. (2016). The nativist triangle: Sexuality, race, and religion in discourses on "Dutchness." In J.W. Duyvendak, P. Geschiere, \& E. Tonkens (Eds.), The culturalization of citizenship: Belonging and polarization in a globalizing world (pp. 97-112). London: Palgrave Macmillan.

Banton, M. (1999). The idiom of race: A critique of presentism. In L. Back, J. Solomos (Eds.), Theories of race and racism: A reader (pp. 55-67). London and New York: Routledge.

Barth, F. (1969). Ethnic groups and boundaries: The social organization of culture difference. Bergen, Oslo, Troms $\varnothing$ : Universitetsforlaget. 
Centraal Bureau voor de Statistiek (CBS) (2016). Jaarrrapport integratie 2016. November: Den Haag, Heerlen, Bonaire.

Crenshaw, K. (1989). Demarginalizing the intersection of race and sex: A Black feminist critique of antidiscrimination doctrine, feminist theory and antiracist Politics. University of Chicago Legal Forum, 1(8), 139-167.

De Kom, A. (1934). Wij slaven van Suriname. Amsterdam: Uitgeverij Atlas Contact.

Essed, P. (1984). Alledaags racisme. Amsterdam: Feministische Uitgeverij Sara.

Essed, P. (1990). Everyday racism: Reports from women of two cultures. Alameda, CA: Hunter House.

Essed, P., \& Hoving, I. (2014). Innocence, smug ignorance, resentment: An introduction to Dutch racism. In P. Essed, \& I. Hoving (Eds.), Dutch racism: Intersecting place, sex and race (pp. 9-30). Amsterdam, New York: Editions Rodopi B.V.

Fadil, N., De Koning, M., \& Ragazzi, I. (2019). Introduction. Radicalization: Tracing the trajectory of an "empty signifier" in the low lands. In N. Fadil, M. De Koning, \& I. Ragazzi (Eds.), Radicalization in Belgium and The Netherlands: Critical perspectives on violence and security (pp. 10-34). London: IB Tauris (in Press).

Goldberg, D.T. (2006). Racial Europeanization. Ethnic and Racial Studies 29(2), 331-364.

Hira, S. (2012). Decolonizing the mind: The case of the Netherlands. Human Architecture: Journal of the Sociology of Self-Knowledge, 10(1), 53-68.

Hoefte, R. (2014). Suriname in the long twentieth century: Domination, contestation, globalization. New York: Palgrave Macmillan.

Jacobson, M.F. (1999). Introduction: The fabrication of race. In M.F. Jacobson (Ed.), Whiteness of a different color: European immigrants and the alchemy of race (pp. 114). Cambridge, MA: Harvard University Press.

Klinkers, I., \& Oostindie, G. (2003). Introduction. In I. Klinkers \& G. Oostindie (Eds.), Decolonising the Caribbean: Dutch policies in a comparative perspective (pp.9-16). Amsterdam: Amsterdam University Press.

Koning, E. (2018). Zwarte Piet, een Blackface Personage: een Eeuw aan Blackfacevermaak in Nederland. Tijdschrift voor Geschiedenis, 131(4), 551-575.

Linnaeus, C. (1735). Systema naturae, sive Regna tria naturae. Systematice proposita per Classes, Ordines, Genera, \& Species. Leiden: Lugduni Batavorum, Apud Theodorum Haak.

Misérus, M., \& Van De Kolk, T. (2016, November 5). Van roetveegpiet tot 'intens' zwarte piet: dit doen de gemeenten bij de intocht. De Volkskrant. Retrieved from 
https://www.volkskrant.nl/nieuws-achtergrond/van-roetveegpiet-tot-intens-zwarte-pietdit-doen-de-gemeenten-bij-de-intocht $\sim \mathrm{b} 9 \mathrm{~d} 9 \mathrm{a} 047 /$

Morris-Reich, A., \& Rupnow, D. (2017). Introduction. In A. Morris-Reich, \& D. Rupnow (Eds.), Ideas of "race" in the history of the humanities (pp. 1-32). New York: Palgrave Macmillan.

Nimako, K. (2012). About them, but without them: Race and ethnic relations studies in Dutch universities. Human Architecture: Journal of the Sociology of Self-Knowledge, 10(1), 45-52.

Nimako, K., \& Small, S. (2012, July). Public history, collective memory and competing representations of slavery and its legacies in England and the Netherlands. Paper presented at International Political Science Association Annual Conference, Madrid, Spain.

Nzume, A. (2017). Hallo witte Mensen. Amsterdam: Amsterdam University Press.

Oostindie, G. (2010). Introduction. In G. Oostindie (Ed.), Postcolonial Netherlands: Sixty-five years of forgetting, commemorating, silencing (pp. 7-22). Amsterdam: Amsterdam University Press.

Özdil, Z. (2015). Nederland mijn Vaderland. Amsterdam and Antwerp: De bezige Bij.

Rodenberg, J. and Wagemaker, P. (2016). Essentializing "Black Pete": Competing narratives surrounding the Sinterklaas tradition in the Netherlands. International Journal of Heritage Studies, 22(9), 716-728.

Said, E. (1994). Overlapping territories, intertwined histories. In E. Said (Ed.), Culture and Imperialism (pp.3-61). New York, NY: Vintage Books.

Takken, W., \& Metselaar, D. (2019, September 17). NRC Handelsblad. Retrieved from https://www.nrc.nl/nieuws/2019/09/17/voor-het-eerst-alleen-roetveegpieten-tijdenslandelijke-sinterklaasintocht-a3973599

Van Niekerk, M. (2004). Afro-Caribbeans and Indo-Caribbeans in the Netherlands:

Premigration legacies and social mobility. The International Migration Review, 38(1), 158-183.

Verwey-Jonker, H. (1971). Allochtonen in Nederland: Beschouwingen over de: Gerepatrieerden, Ambonezen, Surinamers, Antillianen, Buitenlandse Werknemers, Chinezen, Vluchtelingen, Buitenlandse Studenten in onze Samenleving. The Hague: Staatsuitgeverij, Ministerie van Cultuur, Recreatie en Maatschappelijk Werk.

Visweswaran, K. (1998). Race and the culture of anthropology. American Anthropologist, 100(1), 70-83. 
Weiner, M.F. (2014). (E)racing slavery: Racial neoliberalism, social forgetting, and scientific colonialism in Dutch primary school history textbooks. Du Bois Review, 11(2), 329351.

Wekker, G. (2014). Diving into the wreck: Exploring intersections of sexuality, "race," gender, and class in the Dutch cultural archive. In P. Essed, \& I. Hoving (Eds.), Dutch racism: Intersecting place, sex and race (pp. 159-178). Amsterdam, New York: Editions Rodopi B.V.

Wekker, G. (2016). White innocence: Paradoxes of colonialism and race. Durham, London: Duke University Press.

Wekker, G. (2018). Witte onschuld: Paradoxen van kolonialisme en ras. Amsterdam: Amsterdam University Press. 